\title{
Lombociatalgia: Comparação da Analgesia entre Metilprednisolona, Fentanil e Metilprednisolona com Fentanil, Associados à Bupivacaína, por via Peridural *
}

\section{Low Back Pain: Comparison of Epidural Analgesia with Bupivacaine Associated to Methylprednisolone, Fentanyl and Methylprednisolone plus Fentanyl}

Quitéria Maria Wanderley Rocha ${ }^{1}$, Rioko Kimiko Sakata, TSA ${ }^{2}$, Adriana Machado Issy, TSA $^{2}$

\section{RESUMO}

Rocha QMW, Sakata RK, Issy AM - Lombociatalgia: Comparação da Analgesia entre Metilprednisolona, Fentanil e Metilprednisolona com Fentanil, Associados à Bupivacaína, por via Peridural

Justificativa e Objetivos - Os corticosteróides têm sido empregados no espaço peridural, como alternativa de tratamento da lombalgia refratária às medidas conservadoras. Os opióides têm efeito analgésico através da ligação a receptores da medula espinhal e poderiam ter efeito somatório. Este estudo teve como objetivo avaliar a eficácia, os efeitos colaterais e as complicações de opióide e corticosteróide associados ao anestésico local, para tratamento da lombalgia e lombociatalgia aguda, provocadas por hérnia de disco.

Método - Foram avaliados 45 pacientes adultos portadores de hérnia de disco. O grupo G-I recebeu $8 \mathrm{ml}$ de bupivacaína a 0,25\% com metilprednisolona $(80 \mathrm{mg})$; o grupo $\mathrm{G}-\mathrm{Il}, 8 \mathrm{ml}$ de bupivacaína a 0,25\% com fentanil $(100 \mu \mathrm{g})$ e o grupo G-III, $6 \mathrm{ml}$ de bupivacaína a $0,25 \%$ com fentanil $(100 \mu \mathrm{g})$ e metilprednisolona ( $80 \mathrm{mg}$ ). Havendo necessidade de repetição, nova injeção foi feita após 1 semana e 2 semanas no espaço intervertebral, ou próximo ao da localização da hérnia de disco. O efeito analgésico foi mensurado através de escala verbal.

Resultados - Aos 30 minutos, 6, 12 e 24 horas após o procedimento não houve diferença entre os grupos quanto ao alívio da dor. No quarto, sétimo e $14^{\circ}$ dias, os grupos GI e GIII mostraram melhor alívio da dor, não havendo diferença estatística entre esses grupos. No grupo Gll houve maior necessidade para repetir a injeção no $7^{\circ}$ dia $(G I=33,3 \%$; $G I I=$ $100 \%$ e $\mathrm{G} I I=33,3 \%$ ), e no $14^{\circ}$ dia $(\mathrm{Gl}=6,6 \%$; $\mathrm{G} \|=86,6 \%$ e $G I I I=6,6 \%)$. A utilização de tramadol foi maior no GII. No GI, houve cefaléia (1 paciente); no Gll, sonolência (2 pacientes) e prurido (1 paciente) e no GIII, prurido (1 paciente) e sonolência (1 paciente).

Conclusões - O citrato de fentanil não tem efeito duradouro no controle da dor da hérnia de disco e não melhora o efeito analgésico quando associado a bupivacaína e metilprednisolona por via peridural.

* Recebido da (Received from) Disciplina de Anestesiologia, Dor e Terapia Intensiva da Universidade Federal de São Paulo da Escola Paulista de Medicina (UNIFESP-EPM), São Paulo, SP

1. Anestesiologista, Doutora da Disciplina de Anestesiologia, Dor e Terapia Intensiva da UNIFESP-EPM, São Paulo, SP

2. Professora Adjunta da Disciplina de Anestesiologia, Dor e Terapia Intensiva da UNIFESP-EPM, São Paulo, SP

Apresentado (Submitted) em 04 de janeiro de 2001

Aceito (Accepted) para publicação em 19 de março de 2001

Correspondência para (Mail to)

Dra. Rioko Kimiko Sakata

$R$. Três de Maio 61/51 - Vila Clementino

04044-020 São Paulo, SP

(C) Sociedade Brasileira de Anestesiologia, 2001
UNITERMOS - ANALGÉSICOS, Opióides: fentanil; DOR, Aguda: lombar; DROGAS, Corticosteróides: metilprednisolona

\section{SUMMARY}

Rocha QMW, Sakata RK, Issy AM - Low Back Pain: Comparison of Epidural Analgesia with Bupivacaine associated to Methylprednisolone, Fentanyl and Methylprednisolone plus Fentanyl

Background and Objectives - Epidural steroids are used as an alternative for the treatment of low back pain refractory to conservative measures. Opioids exert their analgesic effect through binding to spinal cord receptors and may have an additive effect. This study aimed at evaluating efficacy, side-effects and complications of opioids and steroids associated to local anesthetics in the treatment of acute low back pain caused by herniated disks.

Methods - Participated in this study 45 adult patients with acute herniated disks. G-I received $8 \mathrm{ml}$ of $0.25 \%$ bupivacaine with methylprednisolone acetate $(80 \mathrm{mg}) ; \mathrm{G}-1 /$ received $8 \mathrm{ml}$ of $0.25 \%$ bupivacaine with fentanyl $(100 \mu \mathrm{g})$ and $\mathrm{G}-\mathrm{III}$ received 6 $\mathrm{ml}$ of $0.25 \%$ bupivacaine with fentanyl $(100 \mu \mathrm{g})$ and $80 \mathrm{mg}$ methylprednisolone acetate. When needed, a new injection was administered after 1 week and 2 weeks into the herniated disk interspace or close to it. Analgesic effects were evaluated through a verbal scale.

Results - At 30 minutes, 6, 12 and 24 hours there were no differences among groups as to pain relief. In days 4, 7 and 14, groups G-I and G-III had better pain relief without statistical differences between them. Group II needed more repeated injections in days 7 (G-I $=33.3 \% ; G-I /=100 \%$ and $G-I / I=33.3 \%)$ and $14(\mathrm{G}-I=6.6 \%, \mathrm{G}-I I=86.6 \%$ and $\mathrm{G}-I I I=6.6 \%)$. Tramadol was more frequently used in G-II. G-I referred headache (1 patient), G-II somnolence (2 patients) and pruritus (1 patient) and G-III pruritus (1 patient) and somnolence (1 patient).

Conclusions - Fentanyl did not improve analgesia when associated either to epidural bupivacaine plus methylprednisolone or to plain bupivacaine.

KEY WORDS - ANALGESICS, Opioids: fentanyl; DRUGS, Steroids: methylprednisolone; PAIN, Acute: low back pain

\section{INTRODUÇÃO}

A hérnia de disco constitui uma das doenças de maior incidência, representando grande parcela dos atendimentos em Clínicas de Dor. A dor geralmente é intensa, acarretando ingestão de grande quantidade de analgésicos nem sempre com alívio adequado.

Os corticosteróides têm sido empregados no espaço peridural, como alternativa de tratamento da lombociatalgia refratária às medidas conservadoras. 
Alocalização de receptores opióides na substância gelatinosa do corno dorsal da medula espinhal e o importante efeito analgésico dos opióides, resultante da sua ação nesses receptores, abriram nova perspectiva no tratamento da dor ${ }^{1}$. Este estudo teve como objetivo comparar a eficácia, os efeitos colaterais e as complicações do uso, por via peridural, de fentanil e corticosteróide associados a anestésicolocal, para tratamento de lombalgia ou lombociatalgia provocada por hérnia de disco na fase aguda.

\section{MÉTODO}

Após aprovação pela Comissão de Ética Médica e assinatura do consentimento pós-informado pelo paciente, foram estudados 45 pacientes com lombalgia ou lombociatalgia aguda por hérnia de disco (menos de trinta dias de sintomatologia), com dor moderada ou intensa.

O diagnóstico baseou-se na história, no exame físico e nos exames radiológicos.

Foram excluídos da pesquisa os pacientes portadores de úlcera gastroduodenal, doença cardíaca, coagulopatia, diabetes, hipertensão arterial não controlada, síndrome facetária, estenose de canal vertebral, hérnia de disco com incontinência de esfíncter ou paralisia de membros inferiores e os que tinham sido submetidos à laminectomia. Mulheres grávidas ou que estavam amamentando também foram excluídas do estudo.

Os pacientes receberam orientação para não tomarem medicação analgésica 6 horas antes da injeção.

Os pacientes foram divididos em 3 grupos: os do grupo G-I $(n=15)$, receberam $8 \mathrm{ml}$ de bupivacaína a $0,25 \%$ associados a $2 \mathrm{ml}$ de acetato de metilprednisolona ( $80 \mathrm{mg}$ ); os do grupo G-II ( $n=15), 8 \mathrm{ml}$ de bupivacaína a $0,25 \%$ associados a $2 \mathrm{ml}$ de fentanil $(100 \mu \mathrm{g})$ e os do grupo G-III $(n=15), 6 \mathrm{ml}$ de bupivacaína a $0,25 \%$ associados a $2 \mathrm{ml}$ de fentanil $(100 \mu \mathrm{g})$ e $2 \mathrm{ml}$ de metilprednisolona (80 mg).

Inicialmente foi feita cateterização de veia periférica com cateter $20 \mathrm{G}$ e iniciada infusão de solução de Ringer. No espaço intervertebral ou próximo onde se encontrava a hérnia de disco, o espaço peridural foi identificado através da técnica da perda da resistência, utilizando-se agulha de Tuohy $12 \mathrm{G}$. Os pacientes foram avaliados durante 6 horas. Ador foi avaliada através de escala verbal (intensidade da dor: ausente, leve, moderada e intensa). Na alta hospitalar os pacientes receberam formulários onde deveriam anotar a avaliação da dor 12, 24 horas e 4 dias após infiltração. Os pacientes também anotavam a ocorrência de possível efeito colateral.

Ao retornarem no $7^{\circ} \mathrm{dia}$, os pacientes que relataram dor ausente ou leve, foram orientados para retornarem no $14^{\circ}$ dia. Nos pacientes com dor moderada ou intensa foi feita uma segunda injeção por via peridural, com a mesma substância empregada na primeira injeção. Os pacientes foram orientados para retornarem no $14^{\circ}$ dia para avaliação do resultado; quando a dor era ausente ou leve, a conduta era a mesma da avaliação do sétimo dia. Se o paciente apresentasse dor moderada ou intensa, era feita a terceira injeção por via peridural.
Os pacientes receberam orientação para utilizarem paracetamol $500 \mathrm{mg}$ até dois comprimidos cada 4 horas, se apresentassem dor leve ou moderada. Se a dor não aliviasse ou fosse intensa, deveriam tomar tramadol na dose de 50 a 100 mg por via oral, com intervalos mínimos de quatro horas. Os resultados foram submetidos à análise estatística pelos testes de Mann-Withney para comparação dos dados demográficos entre os grupos, Kruskal-Wallis e Comparações Múltiplas para comparação da intensidade da dor nos grupos no período inicial e nos diferentes tempos e Teste do Qui-quadrado para comparar a necessidade de repetição da injeção entre os grupos.

\section{RESULTADOS}

Os pacientes do grupo G-I (9 masculino e 6 feminino) apresentaram média de idade de 45,4 anos; os do grupo G-II (9 masculino e 6 feminino), média de 45,9 anos e os do grupo G-III (8 masculino e 7 feminino), média de 43,6 anos. Os grupos mostraram-se semelhantes quanto a idade e sexo.

As hérnias do espaço $L_{3}-L_{4}$ foram encontradas em 6 pacientes (2 no G-I, 3 no G-II e 1 no G-III); do espaço $L_{4}-L_{5}$ em 23 pacientes ( 8 do G-I, 8 do G-II e 7 do G-III) e do $L_{5}-S_{1}$, em 22 pacientes ( 6 do G-I, 7 do G-II e 9 do G-III).

Todos os pacientes apresentavam dor lombar. Ador foi de início súbito em 12 pacientes, com irradiação para membros inferiores em 40, contratura da musculatura paravertebral em 42 , atrofia dos músculos da coxa e panturrilha em 3 , palpação dolorosa do trajeto do ciático em 40 pacientes, hipoestesia no membro inferior em 27, reflexo Aquileu alterado em 14 e patelar em 4 , sinal de Lasègue positivo em 36 e de Néri, em 26 e a força de dorsiflexão do pé e do hállux, diminuída em 30 pacientes.

Em relação à duração dos sintomas não houve diferença estatisticamente significante entre os grupos. No G-I, a média foi de 15,87 dias; no G-II, de 20,63 dias e no G-III, de 22,37 dias.

Aintensidade da dor inicial foi semelhante nos grupos: moderada (60\% do G-I, $73,3 \%$ do G-II e $60 \%$ do G-III) e intensa (40\% do G-I, $26,7 \%$ de G-II e $40 \%$ do G-III).

A intensidade da dor aos 30 minutos, 6 horas, 12 horas e 24 horas, nos grupos não mostrou diferença estatisticamente significante (Tabela I). Nos $4^{\circ}, 7^{\circ}$ e $14^{\circ}$ dias, houve maior número de pacientes com dor moderada e intensa no G-II que nos grupos I e III, não havendo diferença entre os grupos I e III (Figura 1).

Houve homogeneidade entre os grupos em relação ao uso do paracetamol em todos os tempos estudados. A utilização do tramadol foi diferente no tempo $6 \mathrm{~h}$, quando 3 pacientes do G-I tiveram que utilizá-lo.

Em cinco pacientes do G-I, 15 do G-II e 5 do G-III foi necessário repetir a injeção (Tabela II). A análise estatística mostrou maior necessidade no G-II, sem diferença entre os grupos I e III. Houve maior necessidade de terceira injeção no G-II, não ocorrendo diferença entre G-I e G-III. 
Tabela I - Intensidade da Dor (\%) nos Grupos no Período Inicial e nos Diferentes Tempos

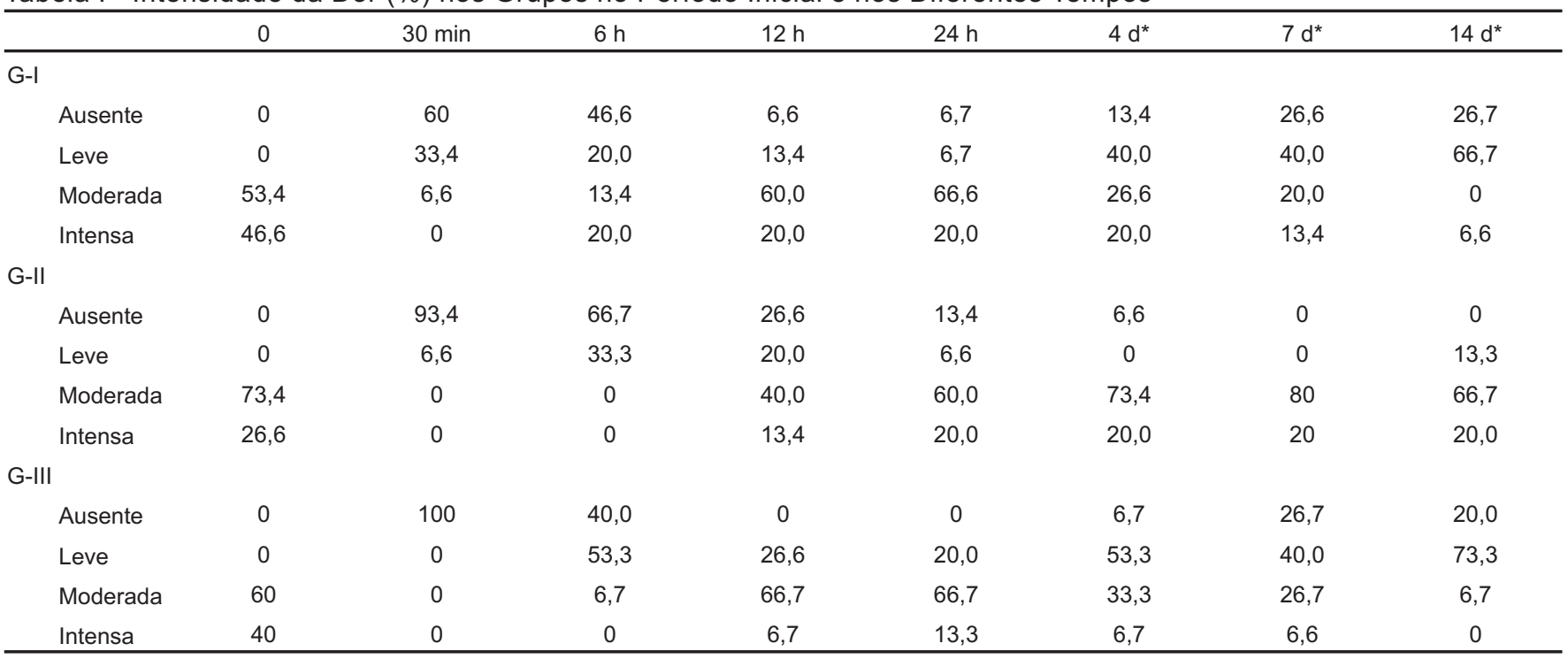

Teste de Kruskal-Wallis, teste de Comparações Múltiplas

* significante $(p<0,05)$, G-II>G-I e G-III nos tempos 4, 7 e 14 dias

No G-I, um paciente apresentou cefaléia. No G-II, dois pacientes apresentaram sonolência e um prurido. No G-III, um apresentou prurido e um, sonolência.

Tabela II - Necessidade de Repetição da Injeção

\begin{tabular}{lcc}
\hline Grupos & \multicolumn{2}{c}{ Repetição Número (\%) } \\
\hline G-I & $2^{\mathrm{a}} \mathrm{n}(\%)$ & $3^{\mathrm{a}} \mathrm{n}(\%)$ \\
G-II & $5(33,3)$ & $1(6,6)$ \\
G-III & $15(100,0)$ & $13(86,6)$ \\
Total & $5(33,3)$ & $1(6,6)$ \\
\hline
\end{tabular}

Teste do Qui-quadrado, $X^{2}$ calculado $=28,8 ; X^{2}$ crítico $=5,99$

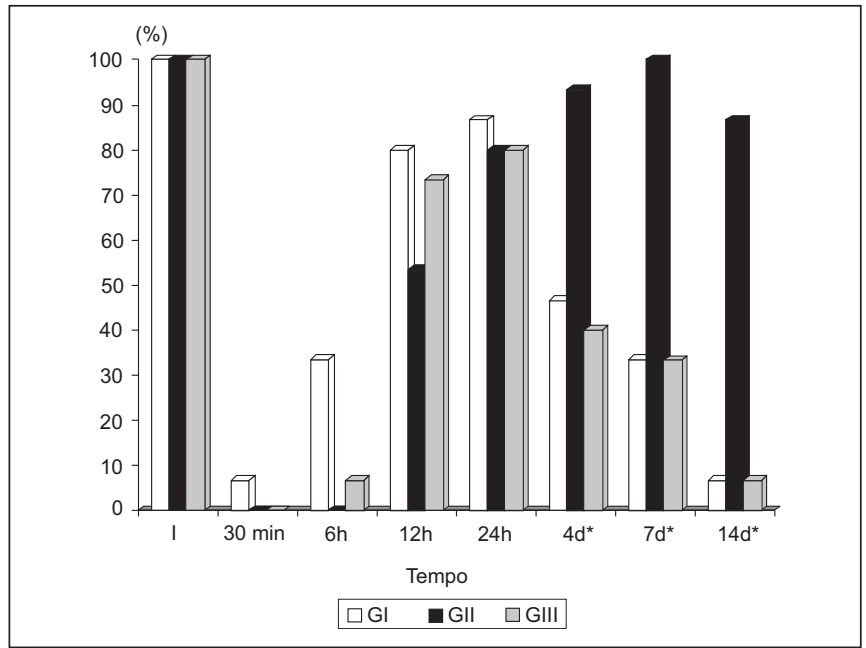

Figura 1 - Porcentagem de Pacientes com Dor Moderada e Intensa nos Diferentes Tempos de Observação

Teste de Kruskal-Wallis, teste de Comparações Múltiplas

* significante, G-II>G-I e G-III nos tempos 4, 7 e 14 dias

Revista Brasileira de Anestesiologia

Vol. 51, № 5, Setembro - Outubro, 2001

\section{DISCUSSÃO}

Optou-se por estudar apenas pacientes com quadro agudo de lombalgia e lombociatalgia, porque as alterações psicológicas que são mais freqüentes nas síndromes dolorosas crônicas poderiam interferir no resultado.

Os pacientes foram submetidos à administração de corticosteróide, opióide ou associação dessas duas medicações, com o intuito de se verificar a ocorrência de potencialização do efeito analgésico, utilizando-se fármacos que têm mecanismos de ação diferentes. Neste estudo foi feita a repetição semanal por se saber que ocorre diminuição do nível plasmático de acetato de metilprednisolona injetado por via peridural, após esse período. Para Benzon ${ }^{2}$ não se justifica mais do que três injeções quando não se observa alívio da dor.

O paracetamol foi empregado para analgesia em pacientes com dor leve a moderada, por não possuir efeito antiinflamatório, interferindo menos nos resultados.

Foi utilizado o tramadol para pacientes com dor intensa, por se tratar de opióide que não causa depressão respiratória ${ }^{3-5}$. Esse fator é importante em decorrência de ter sido utilizado fentanil no espaço peridural e saber-se que a associação de opióides por essas duas vias aumenta a possibilidade de depressão respiratória ${ }^{6}$.

Apesar de não ser constatada diferença significante na intensidade da dor 30 minutos e 6 horas após a injeção, observou-se que nos grupos que receberam fentanil, o alívio da dor foi maior que no que recebeu apenas anestésico local e corticosteróide, provavelmente, em decorrência da somação do efeito do anestésico local com o do opióide.

Alguns mecanismos são sugeridos para explicar o sinergismo da associação do opióide com o anestésico local ${ }^{7}$. Abupivacaína em baixas doses facilita a ligação do opióide ${ }^{8}$ aos receptores e a redução da despolarização provocada pelo 
anestésico local altera a ativação dos canais de cálcio facilitando o efeito do opióide ${ }^{9}$.

Após 12 e 24 horas, a maioria dos pacientes apresentava dor moderada ou intensa provavelmente decorrente do término da ação do anestésico local e do opióide.

Nas avaliações do $4^{\circ}$ e $7^{\circ}$ dias após a injeção, ocorreu diminuição da intensidade da dor nos grupos I e III, provavelmente devido ao início de ação de metilprednisolona. Alguns autores observaram que o efeito dos corticosteróides é gradual entre 1 e 6 dias após a injeção ${ }^{10,11}$.

No $14^{\circ}$ dia, os resultados dos pacientes que receberam corticosteróides foram melhores, mostrando que apenas o corticosteróide mantém a analgesia por períodos maiores.

O alívio da dor pelo corticosteróide é devido ao efeito antiinflamatório, decorrente da inibição da fosfolipase $\mathrm{A}_{2}$ e diminuição da liberação de ácido graxos livres, precursores das prostaglandinas e leucotrienos. Alguns autores acreditam que os esteróides podem modular os receptores n-metil-D-aspartato (NMDA) ${ }^{12,13}$.

O acréscimo do fentanil ao corticosteróide e anestésico local não modifica a necessidade de repetir a injeção, mostrando que, apesar de ter mecanismo de ação diferente, o opióide não tem ação importante.

\section{Low Back Pain: Comparison of Epidural Analgesia with Bupivacaine Associated to Methylprednisolone, Fentanyl and Methylprednisolone plus Fentanyl}

Quitéria Maria Wanderley Rocha, M.D., Rioko Kimiko Sakata, M.D., Adriana Machado Issy, M.D.

\section{INTRODUCTION}

Acute herniated disk is a very frequent disease and represents a major part of a Pain Clinic work. Pain is in general severe leading to the intake of large amounts of analgesics not always with adequate relief.

Epidural steroids have been used as an alternative for low back pain refractory to conservative measures.

The presence of opioid receptors in the gelatinous substance of the spinal chord dorsal horn and the strong analgesic effect of epidural opioids have openned new perspectives for pain treatment ${ }^{1}$.

This study aimed at comparing efficacy, side-effects and complications of epidural fentanyl and steroids associated to local anesthetics for relief of low back pain induced by acute herniated disk.

\section{METHODS}

After the Medical Ethics Committee approval and patient's informed consent, 45 low back pain patients due to herniated disk (less than 30 days of symptoms), with moderate or severe pain participated in this study. The diagnosis was based on history, physical evaluation and radiological results. Exclusion criteria were gastroduodenal ulcer, heart disease, coagulopathy, diabetes, non-controlled hypertension, facet syndrome, vertebral canal stenosis, herniated disk with sphincter incontinence or lower limb paralysis and patients submitted to laminectomy. Pregnant or breast-feeding women were also excluded from the study.

Patients were asked not to take analgesics 6 hours before the injection.

Patients were divided in 3 groups: G-I $(n=15)$ received $8 \mathrm{ml}$ of $0.25 \%$ bupivacaine associated to methylprednisolone acetate $(80 \mathrm{mg}) ; \mathrm{G}-\mathrm{II}(\mathrm{n}=15)$ received $8 \mathrm{ml}$ of $0.25 \%$ bupivacaine associated to $2 \mathrm{ml}$ fentanyl $(100 \mu \mathrm{g})$; and G-III $(n=15)$ received $6 \mathrm{ml}$ of $0.25 \%$ bupivacaine associated to $2 \mathrm{ml}$ fentanyl $(100 \mu \mathrm{g})$ and $2 \mathrm{ml}$ methylprednisolone acetate $(80 \mathrm{mg})$.

A $20 \mathrm{G}$ catheter was inserted in a peripheral vein and lactated Ringer's infusion was started. Epidural injection was performed at the level of the herniated disk or at an interspace close to it, by the loss of resistance technique using a 12G Tuohy needle.

Patients were evaluated for 6 hours. Pain was evaluated by a verbal scale (pain intensity: absent, mild, moderate and severe). At hospital discharge, patients received a form where they should record pain intensity 12 and 24 hours and 4 days after injection. Patients should also record any side-effect. When returning, seven days after, patients referring no pain or moderate pain were told to return in the $14^{\text {th }}$ day. Patients with moderate or severe pain received a second epidural injection of the same substance of the first injection. Patients were then told to return in the $14^{\text {th }}$ day for a new evaluation; when pain was absent or mild, the approach was the same as the $7^{\text {th }}$ day. If patients referred moderate or severe pain, a third epidural injection was applied.

Patients were oriented to take up to 2 tablets of $500 \mathrm{mg}$ paracetamol every 4 hours in case of mild or moderate pain. If there was no pain relief or if it was severe, they were allowed to take 50 to $100 \mathrm{mg}$ tramadol p.o. each 4 hours on a as needed basis.

Results were submitted to statistical analysis using Mann-Whitney test to compare demographics among groups, Kruskal-Wallis and Multiple Comparisons tests to compare pain intensity in all groups in the initial period and different times, and chi-square test was used to compare the need for repeated injections among groups.

\section{RESULTS}

Mean age and gender distribution were similar in all groups: G-I patients 45.4 years ( 9 males and 6 females); G-II 45.9 years ( 9 males and 6 females); and G-III 43.6 years ( 8 males and 7 females).

$L_{3}-L_{4}$ interspace hernias were found in 6 patients ( 2 in G-I, 3 in G-II and 1 in G-III); $L_{4}-L_{5}$ interspace hernias occurred in 23 patients ( 8 in G-I, 8 in G-II and 7 in G-III); and $L_{5}-S_{1}$ interspace 
hernias were found in 22 patients (6 in G-I, 7 in G-II and 9 in G-III).

All patients complained of low back pain. Pain had a sudden onset in 12 patients, was irradiated to lower limbs in 40, caused paravertebral muscles contracture in 42 , atrophy of thigh and calf muscles in 3, painful palpation of the sciatic nerve pathway in 40 patients, lower limb hypoesthesia in 27 , abnormal Achilles reflex in 14 and patellar reflex in 4, positive Lasègue signal in 36 and Néri signal in 26 and decreased foot and halux flexion strength in 30 patients.

The mean symptoms duration were similar in all groups (G-I 15.87 days; G-II - 20.63 days and G-III - 22.37 days). Initial pain intensity was similar in all groups: moderate $(60 \%$ in G-I, $73.3 \%$ in G-II and 60\% in G-III) and severe (40\% in G-I, $26.7 \%$ in G-II and $40 \%$ in G-III).

There were no significant differences in pain intensity at 30 minutes, 6 hours, 12 hours and 24 hours among groups. (Table I). In days 4, 7 and 14, there were more G-II patients with moderate and severe pain as compared to groups I and III, without differences between groups I and III (Figure 1).

The use of paracetamol as rescue analgesic medication was the same in all moments studied for the three groups. Tramadol, however, was needed in three patients in the GI group at 6 hours.

Epidural injection had to be repeated in 5 G-I, 15 G-II and 5 G-III patients (Table II). Statistical analysis has shown a higher frequency of epidural injections in G-II without significant differences between groups I and III. A third injection was more frequent in G-II, without difference between groups I and III. One G-I patient referred headache. Two G-II patients referred somnolence and one pruritus. One G-III patient referred pruritus and one somnolence.

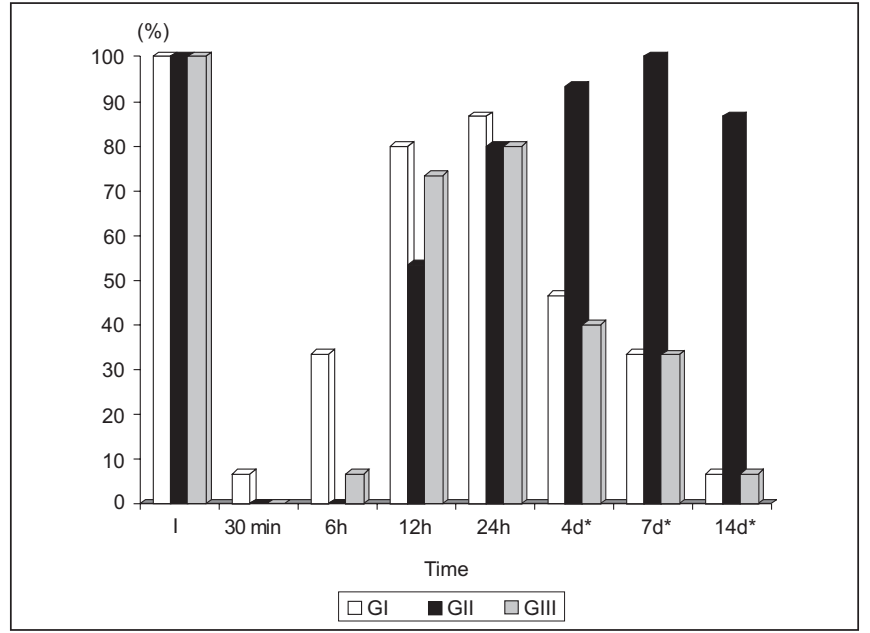

Figure 1 - Patients \% of Moderate and Severe Pain and Different Times Observed

Kruskal-Wallis test, Multiples Comparations test

* significance, G-II>G-1 in times 4, 7 and 14 days

Table II - Number of Patients who Needed Repeated Epidural Injections

\begin{tabular}{lcc}
\hline Groups & \multicolumn{2}{c}{ Repetition Number (\%) } \\
\hline G-I & $2^{\text {nd }} \mathrm{n}(\%)$ & $3^{\text {rd }} \mathrm{n}(\%)$ \\
G-II & $5(33.3)$ & $1(6.6)$ \\
G-III & $15(100.0)$ & $13(86.6)$ \\
Total & $5(33.3)$ & $1(6.6)$ \\
\hline
\end{tabular}

Chi-square test, $X^{2}$ calculated $=28.8 ; X^{2}$ critical $=5.99$

Table I - Pain Intensity (\% of patients) in the Initial Period and Different Times

\begin{tabular}{|c|c|c|c|c|c|c|c|c|}
\hline & 0 & $30 \mathrm{~min}$ & $6 \mathrm{~h}$ & $12 \mathrm{~h}$ & $24 \mathrm{~h}$ & $4 \mathrm{~d}^{*}$ & $7 \mathrm{~d}^{*}$ & $14 \mathrm{~d}^{*}$ \\
\hline \multicolumn{9}{|l|}{ G-I } \\
\hline Absent & 0 & 60 & 46.6 & 6.6 & 6.7 & 13.4 & 26.6 & 26.7 \\
\hline Mild & 0 & 33.4 & 20.0 & 13.4 & 6.7 & 40.0 & 40.0 & 66.7 \\
\hline Moderate & 53.4 & 6.6 & 13.4 & 60.0 & 66.6 & 26.6 & 20.0 & 0 \\
\hline Severe & 46.6 & 0 & 20.0 & 20.0 & 20.0 & 20.0 & 13.4 & 6.6 \\
\hline \multicolumn{9}{|l|}{ G-II } \\
\hline Absent & 0 & 93.4 & 66.7 & 26.6 & 13.4 & 6.6 & 0 & 0 \\
\hline Mild & 0 & 6.6 & 33.3 & 20.0 & 6.6 & 0 & 0 & 13.3 \\
\hline Moderate & 73.4 & 0 & 0 & 40.0 & 60.0 & 73.4 & 80 & 66.7 \\
\hline Severe & 26.6 & 0 & 0 & 13.4 & 20.0 & 20.0 & 20 & 20.0 \\
\hline \multicolumn{9}{|l|}{ G-III } \\
\hline Absent & 0 & 100 & 40.0 & 0 & 0 & 6.7 & 26.7 & 20.0 \\
\hline Mild & 0 & 0 & 53.3 & 26.6 & 20.0 & 53.3 & 40.0 & 73.3 \\
\hline Moderate & 60 & 0 & 6.7 & 66.7 & 66.7 & 33.3 & 26.7 & 6.7 \\
\hline Severe & 40 & 0 & 0 & 6.7 & 13.3 & 6.7 & 6.6 & 0 \\
\hline
\end{tabular}

Kruskal-Wallis test, Multiple Comparisons test,

* Significant $(p<0.05)$, G-II>G-I and G-III in moments 4, 7 and 14 days 


\section{DISCUSSION}

Only patients with acute low back pain were studied because psychological alterations, which are frequent in chronic painful syndromes could interfere in the results.

Patients received steroids, opioids or an association of both drugs to verify potentiation of the analgesic effect by drugs with different mechanisms of action. A weekly repetition was adopted because it is known that there is a decrease in epidural methylprednisolone plasma levels after this period. Ben$z^{2}{ }^{2}$ believes that more than three injections are not justificable when there is no pain relief.

Paracetamol was used for rerscue analgesia in patients with mild or moderate pain because it has no anti-inflammatory effect thus interfering less on the results, and tramadol was used in case of severe pain for being an opioid not causing respiratory depression ${ }^{3-5}$. This is important because epidural fentanyl was used and it is known that the association of opioids increase the possibility of respiratory depression ${ }^{6}$.

Although no significant differences in pain intensity were observed either at 30 minutes or 6 hours after epidural injection, groups receiving fentanyl showed a tendency for better pain relief as compared to the group receiving local anesthetics and steroids alone, probably due to the additive effect of local anesthetics plus opioids.

Some mechanisms are suggested to explain the synergy of the association of opioids and local anesthetics ${ }^{7}$. Low bupivacaine doses facilitate opioids binding to receptors and the depolarization decrease caused by local anesthetics changes calcium channels activation, thus facilitating the opioid effect $^{9}$.

After 12 and 24 hours, most patients referred moderate or severe pain, probably due to the end of local anesthetics and opioids action.

When evaluating patients at the $4^{\text {th }}$. and the $7^{\text {th }}$. day after injection, there was a significant decrease in pain intensity in groups I and III, probably due to methylprednisolone. Some authors have observed that steroid effects increase gradually between 1 and 6 days after injection ${ }^{10,11}$. In the $14^{\text {th }}$. day, patients receiving steroids had better results showing that steroids alone could maintain analgesia for longer periods. a consequence of phospholipase $\mathrm{A}_{2}$ inhibition and decrease of free fatty acids release, prostaglandins and leucotriens precursors. Some authors believe that steroids may modulate $n$-methyl-D-aspartate (NMDA) receptors ${ }^{12,13}$

The addition of fentanyl to steroids and local anesthetics did not change the frequency of epidural injections, showing that, although having a different mechanism of action, opioids did not improve the effect of epidural steroid injections.
Steroid pain relief is caused by the anti-inflammatory effect as

\section{REFERÊNCIAS - REFERENCES}

01. Snyder SH - Opiate receptors and internal opiates: Sci Am, 1977;44-56.

02. Benzon HT - Epidural steriod injections for low back pain and lumbosacral radiculopathy: reviews. Pain, 1971;24:277-295.

03. Houmes RJ, Vofts MA, Verkaaik A et al - Efficacy and safety of tramadol versus morphine for moderate and severe postoperative pain with special regard to respiratory depression. Anesth Analg, 1992;510-514.

04. Preston KL, Jasinski D, Tosta M - Abuse potencial and pharmacological comparison of tramadol and morphine. Drug Alcohol Depend, 1991;27:7-17.

05 . Vickers MD, O'Flaherty D, Szekely SM et al - Tramadol: pain relief by an opioid without depression of respiration. Anaesthesia, 1992;291-296.

06. Etches RC, Sandler AN, Daley MD - Respiratory depression and spinal opioids. Can J Anaesth, 1989;165-185.

07. Brennum J, Petersen KI, Horn A et al - Quantitative sensory examination of epidural anaesthesia and analgesia in man- combination of morphine and bupivacaine. Pain, 1994;56:327-337.

08. Tejwani GA, Rattan AK, Mcdonald JS - Role of spinal opioid receptors in the antinociceptive intrathecal morphine and bupivacaine. J Bone Jt Surg, 1992;726-734.

09. Penning Rk, Yaksh PL - Interaction of intratecal morphine with bupivacaine and lidocaine in the rat. Anesthesiology, 1992;77: 1186-1200.

10. Dilke FW, Burry HC, Grahame R - Epidural corticosteroid injection in management of lumbar nerve root compression. $\mathrm{Br}$ Med J, 1973;2:635-637.

11. Haddox JD - Lumbar and cervical epidural steroid therapy. Anaesth Clin Nosth Am 1992;1: 179-203.

12. Irwin RP, Rogawski MA, Purdy RH et al - Steroid potentiation and inhibition of N-Methil-D-Aspartato receptor-mediated intracelular $\mathrm{Ca}^{++}$responses: struture-activity studies. J Pharmacol Exp Ther, 1994;677-682.

13. Mathis C, Paul SM, Crawley JN - The neurosteroid pregnenolone sulfate blocks NMDA antagonist-induced deficits in a passive avoidance memory task. Psychopharmacology, 1994;116: 201-206.

\section{RESUMEN}

Rocha QMW, Sakata RK, Issy AM - Lumbociatalgia: Comparación de la Analgesia entre Metilprednisolona, Fentanil y Metilprednisolona con Fentanil, Asociados a la Bupivacaína, por vía Peridural

Justificativa y Objetivos - Los corticosteroides han sido empleados en el espacio peridural, como alternativa de tratamiento de la lumbalgia refractaria a las medidas conservadoras. Los opioides tienen efecto analgésico a través de la ligación a receptores de la médula espinal y podrían tener efecto de suma general. Este estudio tuvo como objetivo evaluar la eficacia, los efectos colaterales y las complicaciones de opioide y corticosteroide asociados al anestésico local, para tratamiento de la lumbalgia y lumbociatalgia aguda, provocadas por hernia de disco.

Método - Fueron evaluados 45 pacientes adultos portadores de hernia de disco. El grupo G-I recibió $8 \mathrm{ml}$ de bupivacaína a 0,25\% con metilprednisolona (80 mg); el grupo G-II, $8 \mathrm{ml}$ de bupivacaína a 0,25\% con fentanil $(100 \mu \mathrm{g})$ y el grupo G-III, $6 \mathrm{ml}$ de bupivacaína a $0,25 \%$ con fentanil $(100 \mu \mathrm{g})$ y metilprednisolona $(80 \mathrm{mg})$. Habiendo necesidad de repetición, nueva inyección fue hecha después de 1 semana y 2 semanas,

Revista Brasileira de Anestesiologia
Vol. 51, № 5 , Setembro - Outubro, 2001 
LOW BACK PAIN: COMPARISON OF EPIDURAL ANALGESIA WITH BUPIVACAINE ASSOCIATED TO METHYLPREDNISOLONE, FENTANYL AND METHYLPREDNISOLONE PLUS FENTANYL

en el espacio intervertebral, o próximo al de la localización de la hernia de disco. El efecto analgésico fue medido a través de escala verbal.

Resultados - A los 30 minutos, 6, 12 y 24 horas después del procedimiento no hubo diferencia entre os grupos cuanto al alivio del dolor. En el cuarto, séptimo e $14^{\circ}$ días, los grupos Gl y GIII mostraron mejor alivio del dolor, no habiendo diferencia estadística entre esos grupos. En el grupo Gll hubo mayor necesidad para repetir la inyección en el $7^{\circ}$ día ( $G /=33,3 \%$;
$G I I=100 \%$ y $G I I=33,3 \%$ ) y en el $14^{\circ}$ día $(G I=6,6 \%$; $G I I=86,6 \%$ y $G I I I=6,6 \%)$. La utilización de tramadol fue mayor en el GII. En el Gl, hubo cefalea (1 paciente); en el Gll, somnolencia (2 pacientes) y prurito (1 paciente) y en el GIII, prurito (1 paciente) y somnolencia (1 paciente).

Conclusiones - El citrato de fentanil no tiene efecto duradero en el control del dolor de la hernia de disco y no mejora el efecto analgésico cuando asociado a bupivacaína y metilprednisolona por vía peridural. 